\title{
Willingness to attend cardiopulmonary resuscitation training and the associated factors among adults in China
}

\author{
Shijiao Yan ${ }^{1,2+}$, Yong Gan ${ }^{3+}$, Rixing Wang ${ }^{4}$, Xingyue Song ${ }^{2,4}$, Ning Zhou ${ }^{5^{*}}$ and Chuanzhu Lv²,4,6,7*
}

Keywords: Out-of-hospital cardiac arrest, Resuscitation, Cardiopulmonary resuscitation, Willingness, Training, China

Out-of-hospital cardiac arrest (OHCA) is an important public health challenge worldwide [1]. The survival rate of OHCA is less than $1 \%$ in China compared with $12 \%$ in the USA [2]. Previous studies have shown that immediate bystander-initiated cardiopulmonary resuscitation (CPR) and early defibrillation are essential to improve survival after OHCA [3]. However, the bystander CPR and CPR training rates remain insufficient, even in Western countries. This observational, national, cross-sectional survey aimed to investigate the prevalence of previous CPR training and willingness to be trained in CPR in the Chinese adults and to determine the associated factors.

A cross-sectional study was carried out in China from December 2018 to February 2019. A multistage stratified random sampling design was used in this study. First, a total of 31 Chinese provinces were classified as developed, developing, and less-developed regions according to per capita household income in 2018. Second, we selected 10 urban communities and 10 rural towns randomly from each province. Third, according to the number of residents and the scale of the community or town, from each sampled community or town, 30\% of the residents who had lived in that county (or district) for at least 6 months were randomly selected to complete a self-administered questionnaire. Figure 1 shows the flowchart for recruitment and response rates. The questionnaire was shown in Supplement.

Among the 99,186 respondents, more than half were women, and $59.9 \%$ were from developed regions. A minority of participants $(37.6 \%)(n=37,278)$ had attended a previous CPR training, and $21.5 \%$ respondents $(n=21$, 299) were familiar with automated external defibrillator (AED).

\footnotetext{
*Correspondence: zjzhou121@163.com; Ivchuanzhu677@126.com

'Shijiao Yan and Yong Gan contributed equally to this work.

${ }^{5}$ Central People's Hospital of Zhanjiang, No. 2 Cunjin Road, Chikan District, Zhanjiang 524037, Guangdong, China

${ }^{2}$ Key Laboratory of Emergency and Trauma of Ministry of Education, Hainan Medical University, Haikou, Hainan, China

Full list of author information is available at the end of the article
} licence and your intended use is not permitted by statutory regulation or exceeds the permitted use, you will need to obtain permission directly from the copyright holder. To view a copy of this licence, visit http://creativecommons.org/licenses/by/4.0/ The Creative Commons Public Domain Dedication waiver (http://creativecommons.org/publicdomain/zero/1.0/) applies to the data made available in this article, unless otherwise stated in a credit line to the data. 


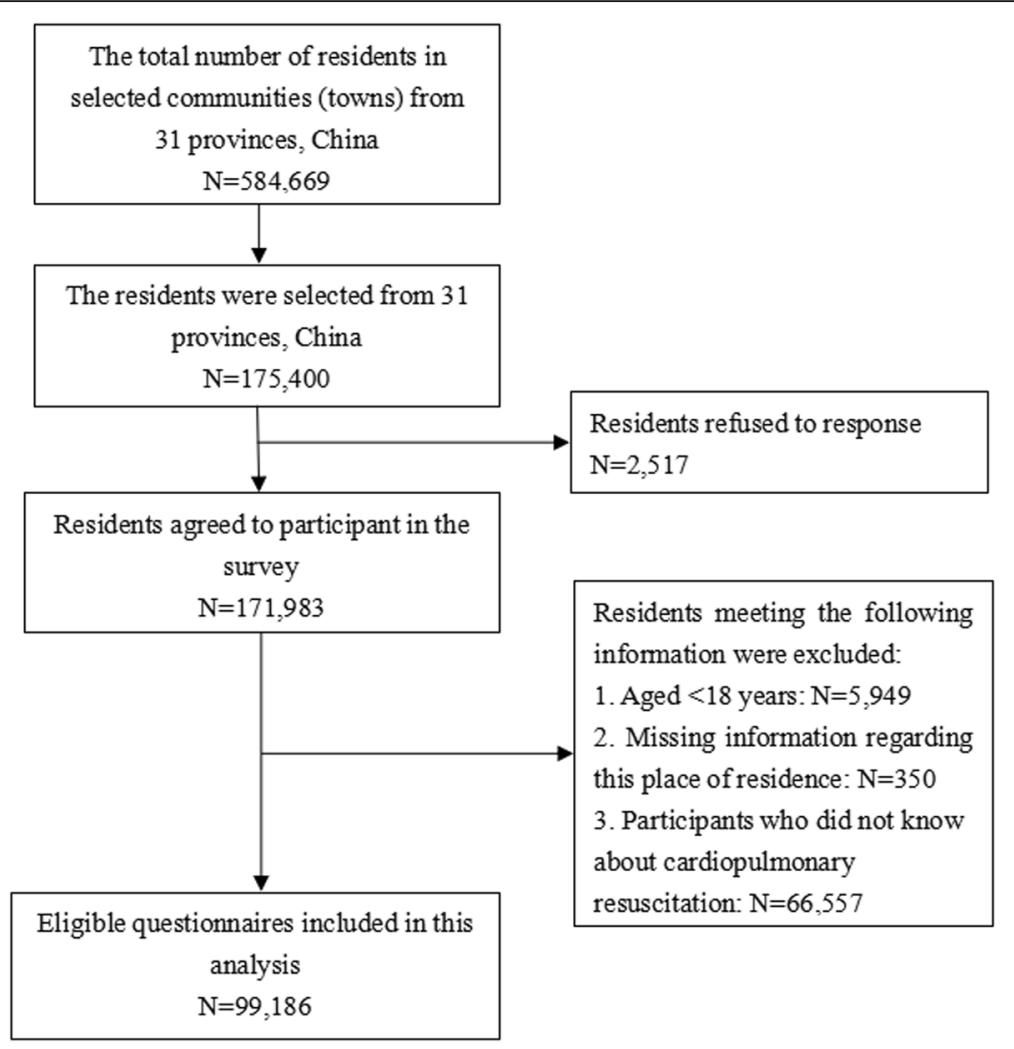

Fig. 1 Flowchart for recruitment and response to the survey

Overall, $73.4 \%$ of participants reported that they were willing to attend CPR training, 9.0\% were unwilling to attend CPR training, and $17.7 \%$ were unsure of their willingness.

Participants who were female $(\mathrm{OR}=1.68)$, had a higher education level (senior high school: $\mathrm{OR}=1.47$; college degree: $\mathrm{OR}=1.77$; bachelor's degree or above: $\mathrm{OR}=$ 2.05 ), and had lower income (middle: $\mathrm{OR}=1.62$; low: $\mathrm{OR}=1.61$ ) were more likely to be willing to learn CPR. In addition, Chinese adults who had prior CPR training $(\mathrm{OR}=1.70)$ and who were familiar with utilizing an AED $(\mathrm{OR}=1.15)$ had high odds of attending CPR training. (Table 1).

The percentage of adults with CPR training was higher than that reported for the general population in Japan (35\%) [4], but lower than in most developed countries, such as Sweden (45\%) [5] and Crimea (53\%) [6]. The differences might be due, at least in part, to differences in sample size and the participants' characteristics, including their socioeconomic status and the CPR training awareness in their national context.

Our study showed that $73.4 \%$ of the respondents were willing to learn $\mathrm{CPR}$, which was higher than in previous studies conducted in other countries [6].
These findings indicate that CPR training is highly acceptable to the public. Previous research has shown that socioeconomic disparities exist with regard to attending CPR training and surviving an OHCA [6]. The findings suggest that willingness to attend CPR training may also correlate with socioeconomic factors, specifically with educational attainment. We identified an independent association between having a higher education level and an increased likelihood of attending CPR training.

No significant association between place of residence and willingness of attend CPR training was found in our study, which was consistent with a previous study [6]. However, a previous study conducted by Axelsson et al. [5] showed that urban residents were more willing to learn CPR. This finding may signal to institutions to provide equal CPR training opportunities and projects for rural and urban residents in China.

The Chinese government should make efforts to optimize and standardize a national model of CPR delivery training and enhance the public awareness and motivation to increase the willingness to attending CPR training. 
Table 1 Logistic stepwise regression analysis for the associationwith the willingness to attend CPR training among adults

\begin{tabular}{|c|c|c|c|c|c|}
\hline Variable & Estimate & $S E$ & Wald & $P$ & $\begin{array}{l}\text { OR } \\
(91 \% \mathrm{Cl})\end{array}$ \\
\hline \multicolumn{6}{|l|}{ Gender (ref. male) } \\
\hline Female & 0.52 & 0.02 & 991.34 & $<0.001$ & $\begin{array}{l}1.67 \\
(1.62-1.73)\end{array}$ \\
\hline Age (ref. 60 ) & & & 48.71 & $<0.001$ & \\
\hline $45 \sim 59$ & 0.32 & 0.05 & 46.06 & $<0.001$ & $\begin{array}{l}1.37 \\
(1.25-1.50)\end{array}$ \\
\hline $18 \sim 44$ & 0.31 & 0.05 & 44.96 & $<0.001$ & $\begin{array}{l}1.37 \\
(1.25-1.50)\end{array}$ \\
\hline \multicolumn{6}{|l|}{ Ethnicity (ref. Han ethnicity) } \\
\hline Minority & 0.08 & 0.03 & 8.95 & 0.003 & $\begin{array}{l}1.08 \\
(1.03-1.14)\end{array}$ \\
\hline $\begin{array}{l}\text { Education level (ref. junior } \\
\text { high school and below) }\end{array}$ & & & 763.31 & $<0.001$ & \\
\hline Senior school & 0.39 & 0.03 & 156.32 & $<0.001$ & $\begin{array}{l}1.47 \\
(1.39-1.57)\end{array}$ \\
\hline College degree & 0.57 & 0.03 & 359.77 & $<0.001$ & $\begin{array}{l}1.77 \\
(1.67-1.88)\end{array}$ \\
\hline $\begin{array}{l}\text { Bachelor degree or } \\
\text { above }\end{array}$ & 0.72 & 0.03 & 701.69 & $<0.001$ & $\begin{array}{l}2.05 \\
(1.94-2.16)\end{array}$ \\
\hline
\end{tabular}

Marital status (ref. unmarried/widow/divorced)

$\begin{array}{llllll}\text { Married } & 0.22 & 0.02 & 108.84 & <0.001 & 1.25 \\ & & & & & (1.19-1.30) \\ \text { Work status (ref. retire) } & & & 76.97 & <0.001 \\ \text { Unemployment } & 0.21 & 0.05 & 19.45 & <0.001 & 1.23 \\ & & & & & (1.12-1.35) \\ \text { Employment } & 0.31 & 0.05 & 48.08 & <0.001 & 1.37 \\ & & & & & \end{array}$

Health insurance (ref. no)

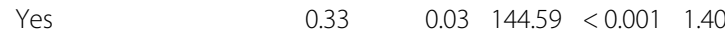

Income status (ref. high)

Middle

Low

0.48

Self-perceived health status (ref. poor)

Fair

Cigarette smoking (ref. $\quad 0.37$ smokers)

Non-smokers

Physical inactivity (ref. yes) $\quad 0.26$

No

History of chronic disease $\quad 0.15$ (ref. yes)
Table 1 Logistic stepwise regression analysis for the associationwith the willingness to attend CPR training among adults (Continued)

\begin{tabular}{|c|c|c|c|c|c|}
\hline Variable & Estimate & $S E$ & Wald & $P$ & $\begin{array}{l}\text { OR } \\
(91 \% \mathrm{Cl})\end{array}$ \\
\hline \multicolumn{6}{|l|}{ No } \\
\hline $\begin{array}{l}\text { Having previous CPR } \\
\text { training (ref. no) }\end{array}$ & 0.53 & 0.02 & 934.69 & $<0.001$ & $\begin{array}{l}1.70 \\
(1.64-1.76)\end{array}$ \\
\hline \multicolumn{6}{|l|}{ Yes } \\
\hline $\begin{array}{l}\text { Familiarity with utilizing } \\
\text { an AED (ref. no) }\end{array}$ & 0.14 & 0.02 & 47.17 & $<0.001$ & $\begin{array}{l}1.15 \\
(1.11-1.20)\end{array}$ \\
\hline \multicolumn{6}{|l|}{ Yes } \\
\hline Constant & -2.21 & 0.07 & 969.67 & $<0.001$ & 0.11 \\
\hline
\end{tabular}

Abbreviations: $A E D$ automated external defibrillator, $C P R$

cardiopulmonary resuscitation

\section{Supplementary information}

Supplementary information accompanies this paper at https://doi.org/10. 1186/s13054-020-03165-1.

\section{Additional file 1.}

\section{Abbreviations}

AED: Automated external defibrillator; Cl: Confidence interval;

CPR: Cardiopulmonary resuscitation; OHCA: Out-of-hospital cardiac arrests; OR: Odds ratio

\section{Acknowledgements}

We would like to thank the study participants and all staff members involved in this study for their efforts in the data collection.

\section{Authors' contributions}

SJY, YG, and CZL conceived and designed the study. SJY, YG, RXW, ZQL, XYS, and QZ participated in the acquisition of data. YG analyzed the data. XYS gave advice on methodology. SJY and YG drafted the manuscript, and SJY, $Y G, X Y S, W N F, N Z$, and CZL revised the manuscript. All authors read and approved the final manuscript. CZL is the guarantor of this work and had full access to all the data in the study and takes responsibility for its integrity and the accuracy of the data analysis.

\section{Funding}

This study was approved by the Research Project of Education and Teaching Reform in Hainan Province (Hnjg2019ZD-16).

Availability of data and materials

Data may be made available by contacting the corresponding author.

\section{Ethics approval and consent to participate}

The study protocol was approved by the Ethics Committee of the Tongj Medical College Institutional Review Board, Huazhong University of Science and Technology, Wuhan, China.

\section{Consent for publication}

Not applicable.

\section{Competing interests}

We declare that we have no conflict of interests.

\section{Author details}

${ }^{1}$ School of Public Health, Hainan Medical University, Haikou, Hainan, China. ${ }^{2}$ Key Laboratory of Emergency and Trauma of Ministry of Education, Hainan Medical University, Haikou, Hainan, China. ${ }^{3}$ Department of Social Medicine and Health Management, School of Public Health, Tongji Medical College, Huazhong University of Science and Technology, Wuhan, Hubei, China. ${ }^{4}$ Department of Emergency, Hainan Clinical Research Center for Acute and 
Critical Diseases, The Second Affiliated Hospital of Hainan Medical University, No. 3 Xueyuan Road, Longhua Zone, Haikou 571199, Hainan, China. ${ }^{5}$ Central People's Hospital of Zhanjiang, No. 2 Cunjin Road, Chikan District, Zhanjiang 524037, Guangdong, China. ${ }^{6}$ Emergency and Trauma College, Hainan Medical University, Haikou, Hainan, China. ${ }^{7}$ Research Unit of Island Emergency Medicine, Chinese Academy of Medical Sciences (No.

2019RU013), Hainan Medical University, Haikou, Hainan, China.

Received: 10 March 2020 Accepted: 9 July 2020

Published online: 23 July 2020

\section{References}

1. Berdowski J, Berg RA, Tijssen JG, Koster RW. Global incidences of out-ofhospital cardiac arrest and survival rates: systematic review of 67 prospective studies. Resuscitation. 2010:81(11):1479-87.

2. Hua W, Zhang LF, Wu YF, Liu XQ, Guo DS, Zhou HL, Gou ZP, Zhao LC, Niu HX, Chen KP, et al. Incidence of sudden cardiac death in China: analysis of 4 regional populations. J Am Coll Cardiol. 2009;54(12):1110-8.

3. Malta Hansen C, Kragholm K, Pearson DA, Tyson C, Monk L, Myers B, Nelson D, Dupre ME, Fosbol EL, Jollis JG, et al. Association of bystander and firstresponder intervention with survival after out-of-hospital cardiac arrest in North Carolina, 2010-2013. JAMA. 2015:314(3):255-64.

4. Kuramoto N, Morimoto T, Kubota Y, Maeda Y, Seki S, Takada K, Hiraide A. Public perception of and willingness to perform bystander CPR in Japan. Resuscitation. 2008;79(3):475-81.

5. Axelsson AB, Herlitz J, Holmberg S, Thoren AB. A nationwide survey of CPR training in Sweden: foreign born and unemployed are not reached by training programmes. Resuscitation. 2006;70(1):90-7.

6. Birkun A, Kosova Y. Social attitude and willingness to attend cardiopulmonary resuscitation training and perform resuscitation in the Crimea. World J Emerg Med. 2018;9(4):237-48.

\section{Publisher's Note}

Springer Nature remains neutral with regard to jurisdictional claims in published maps and institutional affiliations.

Ready to submit your research? Choose BMC and benefit from:

- fast, convenient online submission

- thorough peer review by experienced researchers in your field

- rapid publication on acceptance

- support for research data, including large and complex data types

- gold Open Access which fosters wider collaboration and increased citations

- maximum visibility for your research: over $100 \mathrm{M}$ website views per year

At $\mathrm{BMC}$, research is always in progress.

Learn more biomedcentral.com/submissions 